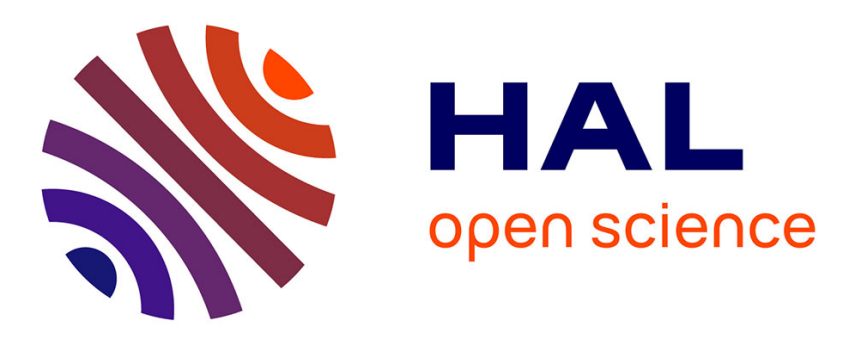

\title{
Consoling Ghosts. Stories of Medicine and Mourning from Southeast Asians in Exile. Jean Langford, Minneapolis: : University of Minnesota Press, 2013, 304 pp \\ Paul Sorrentino
}

\section{To cite this version:}

Paul Sorrentino. Consoling Ghosts. Stories of Medicine and Mourning from Southeast Asians in Exile. Jean Langford, Minneapolis: : University of Minnesota Press, 2013, 304 pp. Medical Anthropology Quarterly, 2014, pp.b1-b4. 10.1111/maq.12117 . halshs-03560425

\section{HAL Id: halshs-03560425 \\ https://shs.hal.science/halshs-03560425}

Submitted on 7 Feb 2022

HAL is a multi-disciplinary open access archive for the deposit and dissemination of scientific research documents, whether they are published or not. The documents may come from teaching and research institutions in France or abroad, or from public or private research centers.
L'archive ouverte pluridisciplinaire HAL, est destinée au dépôt et à la diffusion de documents scientifiques de niveau recherche, publiés ou non, émanant des établissements d'enseignement et de recherche français ou étrangers, des laboratoires publics ou privés. 


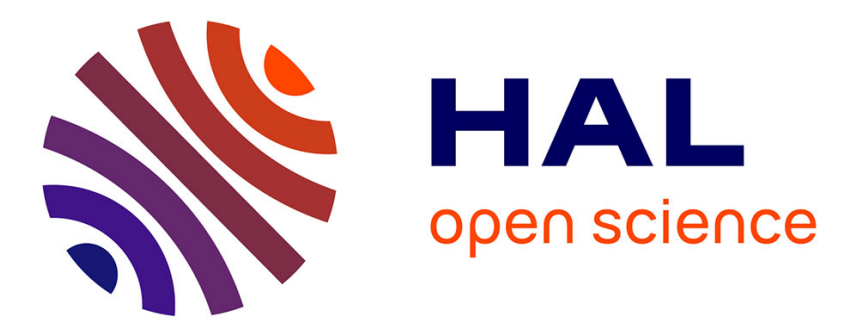

\section{[Compte-rendu] Consoling Ghosts. Stories of Medicine and Mourning from Southeast Asians in Exile. JeanLangford, Minneapolis: : University of Minnesota Press, 2013, 304 pp}

Paul Sorrentino

\section{To cite this version:}

Paul Sorrentino. [Compte-rendu] Consoling Ghosts. Stories of Medicine and Mourning from Southeast Asians in Exile. JeanLangford, Minneapolis: : University of Minnesota Press, 2013, 304 pp. 2014, pp.b1-b4. 10.1111/maq.12117 . halshs-03560425

\section{HAL Id: halshs-03560425 https://halshs.archives-ouvertes.fr/halshs-03560425}

Submitted on 7 Feb 2022

HAL is a multi-disciplinary open access archive for the deposit and dissemination of scientific research documents, whether they are published or not. The documents may come from teaching and research institutions in France or abroad, or from public or private research centers.
L'archive ouverte pluridisciplinaire HAL, est destinée au dépôt et à la diffusion de documents scientifiques de niveau recherche, publiés ou non, émanant des établissements d'enseignement et de recherche français ou étrangers, des laboratoires publics ou privés. 


\section{Consoling Ghosts. Stories of Medicine} and Mourning from Southeast Asians in Exile. Jean Langford, Minneapolis:

University of Minnesota Press, 2013, 304 pp.

Paul Sorrentino

Centre Asie du Sud-Est (EHESS/CNRS)

When Jean Langford started conducting interviews with Southeast Asian emigrants - a word she prefers to immigrants, thus decentering the perspective on displacement-living in the United States about their relation to the dead, she quickly realized that the stories of haunting they told her referred to the secret war in Laos and the Khmer Rouge genocide as much as to American hospices and crematoria. So begins a captivating book where, from damp forest prison camps to refrigerated hospital morgues, in an entanglement of intravenous drips and tropical trees, Langford chooses to examine thanatopolitical regimes (Agamben 1998) of Southeast Asian wartime and U.S. health care with equal attention.

Langford's main purpose is to summon Southeast Asian ghosts so they can "interrogate modern techniques of thanatopolitics and the metaphysical logics that sustain them" (p. 210), and the least I can say is that this undertaking is a success. The reflection departs from haunting, hereby understood as a tendency of the violent past to put the present under siege, stretching experiences of imminent death into immanence (Chapters 1 and 2).

Langford questions the psychodynamic model (dominant in social sciences) that sees violent memories as "forms of failed testimony" to be "healed in the telling" ( $p$. 26). Considering death, this conception of traumatic economy entails a desire, illustrated by the psychoanalytical notion of melancholia, to be "done with mourning" (p. 208). This is made evident by the encounter with Southeast Asian etiologies of haunting that suggests that one should maintain an ongoing relation to the dead, perpetuated in a "lifelong process of mourning" (p. 45).

Inspired by Foucault's (1990) biopolitics, Langford's focus on lifeprolonging technologies as a way to administer the "permission to die" (Chapter 3) provides one of the book's strongest levers. Indeed, the fact that most deaths in American health care institutions are now timed by these technologies has created specific "disciplines of dying" ( $p$. 79).

Combined with the situations of poverty and minoritization in which 
emigrants meet health care institutions, these disciplines may resonate with the "politics of dispensability they remember from war zones and refugee camps" ( $p$. 90). Different "temporalities of dying" ( $p$. 147) appear when monks are only allowed to chant in a chapel, without the patient, while their sutras were meant to prepare his soul for transmigration, or when regulations surrounding resuscitation procedures keep relatives away from the dying while they expect to be in his physical presence when he passes away.

Preventing the "enactment of gradations of death" (p. 201) underlying most Southeast Asian mortuary practices, North American clinical death thus forces a brutal and lonely passage from life to death. Meanwhile, confessional practices of anticipatory grief, based on the idea that moral and psychological debts should be settled before someone dies, become redundant in a Southeast Asian temporality of dying where "the living continue to offer their assistance to those who travel from death to other worlds and finally to rebirth" (p. 151).

The implicit Christian eschatology thus revealed entails not only a strict separation between life and death but also one between body and soul, the former suddenly becoming an empty shell worth no attention when the latter has left it, hence a preference toward memorialization and abstract rememberance from which the corpse is excluded. In contrast, Southeast Asian ritualities summon the dead as embodied presences rather than representational allegories. Relegating the dead to the realm of the symbolic, thanatopolitical institutions combined with social exclusion intercept physical care and gifts intended for the dead in emigrants' mourning practices, which entail an ongoing reciprocity (Chapters 6 and 7). The symbiotic economy of well-being beneficial to both sides is thus interrupted, as the living's failure to nurture the dead translates into the latter's incapacity to intervene as protective entities. This is what "consoling ghosts" is about: They are to be consoled as much as they are expected to console.

This takes us back to the departure point of the book, haunting, but rather understood as the idea that the living and the dead inhabit a shared present. Langford's reflection closes on the perspective of an ethics based on Derrida's (1994) hauntology, asking if " the recognition of the dead as social beings, rather than symbols of sacrifice to social ideals, [might] invite a sense of responsibility to both the dead and the future dead (the living), enabling a certain caution against creating a heavier burden of debt" (p. 208).

A remarkable quality of the book is how, despite mainly interview-based material, Langford mobilizes a great diversity of ethnographic materials and régimes of writing: extensive first-person narratives of emigrants scattered in fragments all across the book, slowly building their density, but also interview quotations, ritual songs, poems, conversations with research assistants, and emigrants' dreams. Langford makes very relevant use of her own expriences of death and dreamed encounters with the dead. I was blown away by a quotation of her unedited field notes (pp. 94-97), where 
a three-page-long list of cases discussed during a nursing staff meeting, each of them cut into a few informative sentences, turns into an absurd litany of lives and deaths dried out by the concrete conditions of work of the hospice personnel.

I would have liked to know more, though, about Langford's choice of an exclusive focus on Lao, Khmer, Khmhu, and Hmong emigrants, and notably about the surprising absence of Vietnamese. The only hint given by the author is that she was originally commissioned by a hospital that had already established ethnicity as the primary variable. Moreover, I found it frustrating that the book repeatedly details similar successions of examples solely to validate the same idea among the four populations, a recurring motif that sometimes weighs down the rhythm of the text and seems to flatten the diversity of Southeast Asia.

The only cases where Langford tries to give more depth to the perspective are her attempts to draw a line separating Buddhasized and non-Buddhasized groups, to which she adds Christian converts (see, e.g., the question of "karmic economies" in Chapter 6). These are relevant parameters, of course, but this exclusive attention does not do justice to the conceptual creativity with which Southeast Asian cultures and individuals manipulate a rich-and often contradictory-diversity of ideas about death. If the book will probably not raise many new questions for scholars studying this region, one should note, however, that it is extremely well documented.

Following the same thread, a greater attention to vernacular categories and their contextual uses (e.g., shiftings between Lao notions of khwan and winyan, hardly discussed in a footnote) would have allowed to develop a proper pragmatics of haunting and mourning. This lack is problematic when it comes to the notion of "body," central to the book. What bodies are Langford's informants actually talking about when they tell their stories of haunting (whether first encounters with corpses left in the trail of wartime violence or their own flesh engaged in present relations with hungry dead relatives ), I would bet that the choices operated between the many words available in the emigrants" mother tongues to express the materiality of existence may provide, if interpreted in context, a useful key to understand the practical forms taken by the engagement with the dead-especially since, as Langford shows it, the strict division between matter and spirit may be irrelevent in Southeast Asia.

This excellent book will definitely be indispensable to whoever is working with Southeast Asian migrants in contexts related to medicine and death, and a precious inspiration for any professional engaged with migrants from other backgrounds. It will also be of great interest for researchers exploring thematics of haunting, mourning, and bioethics of end-of-life. In addition, the extremely refined critique of North American health care institutions and approaches to death, which are partly based on assumptions shared with anthropological scholarship, makes this book recommended reading for Masters' programs seeking to sensitize students to the way encounters with diverse cultural and historical realities can question the 


\section{Book Review}

very categories of anthropological

analysis.

References Cited

Agamben, G.

1998 Homo Sacer: Sovereign Power and

Bare Life. D. Heller-Roazen, trans.

Stanford: Stanford University Press.

Derrida, J.

1994 Spectres of Marx: The State of the

Debt, the Work of Mourning, and the New International. P. Kamuf, trans.

New York: Routledge.

Foucault, M.

1990 The History of Sexuality Vol. 1: An Introduction. R. Hurley, trans. New York: Vintage. 